\title{
LA ESTÉTICA DE LA POESÍA DE DON CIRIACO BOKESA NAPO
}

MBol NaNG

Universidad de Yaundé I

\section{RESUMEN}

El artículo se centra en la organización del material linguístico, en el uso de la palabra poética, en el preciosismo que se observa como obsesión y preocupación primera del autor de Voces de espumas.

Ciriaco Bokesa Napo transmite indirectamente el mensaje según el cual la salvación ante la angustia existencial puede llegar mediante la belleza de la palabra poética. El análisis del léxico del poemario deja ver claramente cómo al mezclar cultismos, coloquialismos y africanismos, el poeta crea una nueva red de relaciones semánticas con fines meramente estéticos. Con don Ciriaco Bokesa Napo, la poesía guineoecuatoriana se instala en su primera Edad de Oro. No se trata de poesías, sino de toda una poética, de toda una estética.

La obra poética de don Ciriaco Bokesa Napo queda poco conocida incluso en África. Hace muy poco la literatura guineoecuatoriana era totalmente desconocida aun entre los propios guineoecuatorianos ${ }^{1}$. La misma historia de la literatura guineoecuatoriana está por escribir.

' DiEUdonNÉ Mendogo M., «Mujer y creación literaria en Guinea Ecuatorial», en Epos núm. XIII, 1997. Pp. 209-218. 
El aislamiento cultural y lingüístico de Guinea Ecuatorial ${ }^{2}$ hace que su literatura quede relegada a un segundo plano cuando se trata de estudiar las letras africanas. Faltan estudios sobre la mayoría de los autores guineanos ${ }^{3} \mathrm{y}$, muy a menudo, quien se atreva a investigar en la literatura de la antigua colonia española, tiene que moverse en campos inexplorados.

Como hispanista y crítico literario africano, me atrevo a creer que uno de nuestros deberes es dar a conocer al mundo de las letras universales la literatura guineoecuatoriana y sacarla de una vez por todas de las trincheras y de la edad de piedra en que sigue encontrándose en los albores del s. XXI. Trabajar, crear, investigar en nuestra propia literatura (sea escrita u oral) debe ser una de nuestras preocupaciones y prioridades.

Nace Ciriaco Bokesa Napo en Basakato de la Sagrada Familia en la isla de Fernando Poo, Bioko Norte, el 19 de diciembre de 1939.

Estudia teología en Salamanca donde tiene la oportunidad de familiarizarse con los poetas del 27 cuyas huellas y sensibilidad son muy apreciables en los versos de Voces de espumas.

En 1980, tras once años de sacerdocio, abandona su oficio y se casa con Teodora Beata.

Es profesor de filología en la Normal, de música, de bubi y español en el Centro Cultural Hispano-Guineano de Malabo, profesor de lengua y literatura españolas en la Escuela de Administración pública, Director adjunto del Centro Cultural Hispano-Guineano.

Ciriaco Bokesa Napo es autor de un solo libro, Voces de espumas ${ }^{4}$,poemario de revuelto asunto, polimétrico, de distintos registros lingüísticos, donde transparenta la influencia de los autores del 27, sobre todo de Jorge Guillén a quien admiró desde sus años de estudiante de filología.

2 Es el único país africano de habla española.

${ }^{3}$ Hubo algunos intentos de estudios. Mencionemos el ya citado de Mendogo sobre Nsue Angüe; Mbare Ngom, «La literatura africana de expresión castellana: la creación literaria en Guinea Ecuatorial, Hispania, núm. 76, 1993, pp. 410-418; MBARE NGOM, Diálogos con Guinea: panorama de la literatura guineoecuatoriana de expresión castellana a través de sus protagonistas, Madrid, Labrys 54, 1996. C. Bokesa Napo, «Ekomo, toda una novela», Africa 2000, núm. 10-11, 1989, pp. 95-97; José Antonio López Hidalgo, «La novela en Guinea Ecuatorial, África 2000, núm. 20, 1993, pp. 42-44.

${ }^{4}$ Ciriaco Bokesa, Voces de espumas, Malabo, Centro Cultural Hispano-Guineano, 1987. El poemario obtuvo el Primer Premio de Poesía en 1985 en el concurso « 12 de octubre», que convoca anualmente el Centro Cultural Hispano-Guineano de Malabo, para conmemorar el aniversario de la independencia de la República de Guinea Ecuatorial y la Fiesta de la Hispanidad. Voces de espumas comporta un umbral. un prólogo, y se divide en siete partes: «Poética», 3 poemas (pp. 1820); «Vocacion», 3 poemas (pp. 21-25); «Amor y paisaje», 22 poemas (pp. 27-49); «Sombras», 6 poemas (pp. 51-59); «Retratos», 6 poemas (pp. 61-70); “Charadas a lo bantú», 6 poemas (pp. 71 81); «Carta final», 3 poemas (pp. 83-90). Cuento los diez epigramas como un solo poema. 
El libro es de una madurez alcanzada a base de preciosismo y de una organización del material lingüístico bien lograda, a pesar de lo que dice el mismo vate:

«Me desenvuelvo muy bien en todos los géneros literarios; y aunque parezca mentira, encuentro la poesía como el género en el que peor me desenvuelvo. El mejor para mí es el ensayo y la narrativa pese a no haber publicado nada al respecto" ${ }^{5}$.

En buen epígono del 27, nos trasmite indirectamente el mensaje según el cual la salvación ante la angustia existencial y metafísica puede llegar mediante la belleza de la palabra poética. Bokesa se ensimisma y se emociona de forma sublime con la palabra poética. Con ella, apostrofa el mundo en su carrera:

Lo exacto, lo bello:

todo, en la palabra

del que posee la voz

hecha de alas, vihuelas y arpas.

No hay matemáticas.

(«El poema», p. 19)

Los primeros textos del poemario constituyen un auténtico manifiesto de poética. Cada uno de los poemas expone un rasgo del habla poética:
No canta mi verso, sino yo en la espuma
canto de lo incierto, al agua, en raudal de vidas,
que agita el viento.
Vaivén perenne
del universo

El mismo título de la obra es significativo. Y según el propio vate, Voces de espumas quiere decir «balbuceos poéticos», voces que da uno para decir que está en el mar de la vida sin ser otra cosa que lo efímero de la espuma ${ }^{6}$.

Me atrevería a decir que Ciriaco Bokesa Napo es un autor ocasional. La miseria ambiente de su país hace que se dedique a la literatura sólo en sus

5 Véase Mbare NGom Faye (1996: 102).

${ }^{6}$ Entrevista concedida a Mbare Ngom Faye. Véase MBare NGOM (1996: 102). 
momentos de ocio. Pese a ello, es un escritor talentuoso, y Voces de espumas, primer libro de poemas escrito en tierras guineanas por un guineano, merece llamar la atención de la crítica.

El poemario presenta un abanico de temas: el transcurso del tiempo, el amor, la vida, el destino, la muerte, la inmortalidad, el mismo arte, las tradiciones africanas, la religión, Dios, son los diferentes elementos que configuran el esqueleto temático del libro.

El vate que se siente preocupado por el porvenir incierto del hombre

\section{Tendido}

sobre los musgos del azar,

escucho el tiempo,

y su interminable enredo de futuros...

(«Un sueño con flores», p. 37)

desemboca en el tema-cliché del Carpe Diem

No es bueno gemir

sobre espinas del tiempo

la suerte pasajera.

Mejor, aprovechar el zumo

de la fruta $[. .$.

$$
\text { («La Rosa», p. 36) }
$$

El viejo motivo del Carpe diem siempre va relacionado con el tema del tiempo a lo Ronsard, y encuentra su máxima expresión en versos jocosos:

ahora que a tus cabellos se enreda aún el aire, ahora que a tu paso danza sus hojas aún el palmeral, besa con tus labios la flor de la vida en rima perfecta.

(«Celia», p. 68)

Pero todo no es voluptuosidad en Bokesa. El vate se interroga sobre la mísera condición humana («Meditación», p. 54), se preocupa por el destino («Camino del mar», p. 35), rehabilita las creencias bubi («Bisila Virgen, p. 46) ${ }^{7}$,

7 Amador Matin del Molino (1989) en su estudio sobre los ritos y creencias de los bubi, anota que Bisila no es sino la Gran Madre del universo. De ella, por obra del espíritu, ha nacido cuanto existe. Lo que hay de fecundidad en el universo a ella se atribuye: de ella brotaron en primer lugar todos los espíritus particulares y en ellos sigue a su lado el elemento fecundo concertado en los espíritus femeninos que los acompañan; y por ella la tierra como energía es madre fecunda 
medita sobre la muerte que le obsesiona. Pues se torna hacia Dios y exclama:

\author{
La tierra es nuestro palacio \\ y nos destierras \\ rumbo al aire de la nada negra. \\ («Morir», p. 57)
}

La poesía de Bokesa también va dirigida a Dios con quien intenta dialogar o a quien dirige sus plegarias («Oración», p. 45; «El Dios que quiero», p. 48). La antítesis entre lo espiritual, lo puro, lo luminoso del paraíso y la oscuridad, la angustia, lo material del mundo, queda reflejada implícito en los dos poemas y traduce el deseo de levitación e impulso ascencional del personaje poemático ${ }^{8}$.

A veces la literatura se hace reflexiva, una autorreflexión sobre el arte de escribir, la misma poesía, los escritores, los filosofos.

El mismo Bokesa (1987: 9) dice que el escritor -y, más aún, el escritor africano-, cuyo mundo de musas se halla atrincherado entre las coordenadas de la inspiración propiamente dicha y el compromiso con un paisaje político hecho válvula de garantías para el triunfo, tiende a poner su pluma al servicio de lo político-social.

que dio el ser al hombre, a los animales y hoy sigue dando el ser a las plantas (pp. 63-64)... En el norte el nombre con que la distinguen es de Bula-bajoka, que significa virgen preciosa, odorifera, perfumada, pues dicen de ella: Atá, baró: a okf rebe: que sin casarse se hallo en estado (p. 64). Sigue diciendo Amador Martín del Molino que todos los días se celebra en el otro mundo la Gran Reunión de los espíritus que cuidan de la Creación. Esta reunión se llama Ritako Ra Eri. Los asuntos de la creación son tratados en esta reunión en la presencia de Eri, el Creador, y de su mujer, Bisila. Según confiesan los "poseídos» de los espíritus, al entrar Bisila en la reunión, los espíritus se callan para darle paso; ella puede entrar y salir cuando quiera... (p. 77). Para más información sobre Bisila, véase Amador Martín del Molino: Los Bubi - Ritos y creencias, Malabo, C.C.H.G., 1989. En el prólogo al mismo libro, Ciciaco Bokesa escribe:

«El descubrimiento de un espíritu femenino como máximo protector de la vida del hombre bubi, el espíritu de la Gran Madre, Bisila, ha merecido el que, por bula pontificia, se dispusieran la coronación solemne de la Gran Madre, Bisila, como patrona de la Archidiocesis de Malabo. Fecundidad y don de hijos fuertes y vigorosos, desde los campos universales de la fe y el amor en los espíritus como manifestación del Único gran Espíritu de Dios, son los quehaceres de esa nueva madre que la Iglesia pone al frente de su pueblo. (Julio de 1989).

${ }^{8}$ Con ello Bokesa nos recuerda a la monja gaditana María Gertrudis de Hore (s. XVIII) y esos versos de MANUEl AltolaguIrRE: «No estarme bajo este techol angustiado de la vidal [...]. Quiero nacer de esta madre/ que es la tierra, al mundo alto» del primer poemario que el vate publicó en su revista Poesía (Málaga, 1, 1930) junto al Cántico espiritual de San Juan de la Cruz y una antología de poemas de Pedro Salinas. 
Sería enjaular un poco el arte. Pero a Bokesa (1987: 9-10) le gusta lo bello:

«En Voces de espumas no hay lugar a peñascos que romper, ni paredes que tirar; no hay altares que eregir, ni otro que el álito en que reside el atributo neto de lo estético. Desde mi concepción del poema, hasta mis charadas más bantú, sólo ensayo una versión: madurar el estilo incubado por lustros bajo el calor del miedo a morir o troncharse. Se trata de un conjunto de cantos, eslabonados entre sí según criterio de afinidades temáticas en torno al instante espacial de lo bello permanente.»

Para conseguir ese bello permanente, el vate empieza por dominar las preceptivas clásicas que no respeta siempre. Escribe en versos simples de arte menor que van desde el bisílabo («Serse», p. 24) hasta el octosílabo («Eva», p. 29). También tenemos versos de arte mayor y versos compuestos. Se observa esa gran diversidad a lo largo de todo el poemario.

Los versos son oxítonos («La vida», p. 45), paroxítonos - los más predominantes- ( Soliloquio, p. 32), proparoxítonos («Soy del Universo», p. 33).

Las estrofas son isométricas («Soliloquio», p. 32); («Soneto personal», p. 31); («La yuca», p. 78), pero predominan las estrofas heterométricas.

La rima de Voces de espumas es oxítona o paroxítona, parcial en general, consonante únicamente en «Soneto personal», suelta en «Palmeras en hileras». Es casi inexistente la rima de timbre ya que predomina el verso libre. En fin, «Lluvia sabrosa» (p. 42) presenta una rima asonante suelta.

El ritmo vacila entre el verso corto y el verso largo. Los versos largos corresponden al auge de la emoción y aceleran el movimiento rítmico. Los versos cortos, en cambio, corresponden a los momentos de descanso. La alternancia de versos largos y cortos nos hace obtener un juego regular de ritmos lentos y rápidos que expresan los diferentes estados anímicos del vate.

La fluidez del ritmo en Bokesa, en muchos casos, se ve rota por abundantes encabalgamientos versales y estróficas. Se podría creer en un primer momento que el uso del encabalgamiento es accidental en el poemario. Pero a medida que vamos avanzando en la lectura de los poemas, lo observamos, como en Blas de Otero 9 , en poemas tan convencionales como el soneto. En el único soneto de Voces de espumas, además de los siete casos de encabalgamientos versales, el primer terceto encabalga sobre el siguiente.

9 El uso del encabalgamiento en Ciriaco Bokesa recuerda al Blas de Otero de Ancia. Es la figura retórica más recurrente de Voces de espumas. 
El empleo de los diferentes patronos rítmicos podrá explicarse a menudo por la casualidad o la mera comodidad del poeta. Pero es fácil identificar en muchos casos factores netamente estéticos. A veces se trata de una adecuación del tema al asunto tratado, adecuación que puede tener base objetiva o bien ser puramente arbitraria y simbólica. De un modo $\mathrm{u}$ otro, el ritmo es un significante que refleja un significado. Otras veces son consideraciones estructurales las que parecen dictar el empleo de tal o cual ritmo, y sobre todo de un cambio de ritmo para acompañar y recalcar la transición de un motivo a otro, o de un aspecto del tema a otro, lo todo envuelto de belleza.

Esa preocupación constante por lo estético, creo, por la preciosidad, es el objetivo príncipe del quehacer poético de Bokesa quien piensa encontrar en ello la gloria:

Quiero la gloria-luz

que no apaga ante la bruma

del vaivén histórico la llama del sagrario,

la del verbo cocido en rescoldo

de los cultos poetas.

(«Gloria, la gloria», p. 55)

Sólo anhelo:

subir a lo alto,

y frotar mis ojos en la punta brillante

de algún astro.

(«Anhelo», p. 25)

También proclama el antiguo alumno de Salamanca:

La gloria, en fin, quiero, gloriosa y áurea, inmortal y humana del lenguaje

dicho y hecho en la palabra cincelada

del poema.

(«Gloria, la gloria», p. 55)

La subida a lo alto de la gloria empieza por la elección y la selección de los vocablos que van a configurar el poema. El vate guineoecuatoriano escribe con pureza y elegancia. El léxico selecto hace que su estilo sea grandilocuente, elevado, varonil, robusto, mestizo, culto.

Como Beaudelaire, Bokesa persigue el oro de la experiencia: la realidad trasciende en el poema, único lugar donde puede ser vivida placenteramente. $\mathrm{El}$ arte no cambia la vida, pero puede hacerla tolerable. El poema es y no es de 
ese mundo: se nutre de vivencias reales y las trasciende: las hace soportables gracias al placer estético que nos procura ${ }^{10}$.

Y se goza con los sustantivos que nos ofrece Bokesa en una bandeja. En Voces de espumas los sustantivos se dividen en concretos (palmeras, monojorocom, rosa, Bisila...) y en abstractos. Los abstractos mantienen entre sí una relación semántica. Algunas se relacionan con el hombre y su existencia (libertad, vida, muerte, soledad). Otros expresan el amor o se relacionan con la poesía o el arte en general, y con el transcurso del tiempo.

Los concretos se refieren a los elementos de la naturaleza y al hombre. Se puede hablar de pájaros, animales, vinos, cigarrillos etc., pero nombrar Benson, Marlboro (p. 75), yuca, malanga, Mahoma, España, moras, África, Bisila, (p. 78 ), etc. es ir de lo abstracto a lo concreto.

Si la herencia del seminario y la sólida formación intelectual de Bokesa hacen que nos encontremos con latinismos,

«Coelum est coelum Domini,
terram autem dedit hominibus».
$Y$, yo me pregunto: in aeternum?
(«Morir», p. 58 )

también abundan africanismos en el poemario: malamba, mongorokom, sawa-sawa, djomba-ya-mbea, mandjá-a, pepe-sup, bokao. Tam-tames, macabo, Bisila...

Las palabras no dicen ni desdicen la materia. El objeto verbal al entrar en un sistema se integra en las reglas sintácticas y semánticas de que sólo Bokesa tiene el secreto y pulsa en su debido momento la tecla que le interesa. Así cualquier objeto nombrado - aun las palabras aparentemente ininteligibles- adquiere legítima relación y refiere el mundo. El vate fuerza de ese modo una nueva red de relaciones semánticas. Se trata del acto de inteligibilidad de que habla George Steiner, que puede trascender la comprensión lógico-racional.

El empleo de expresiones coloquiales y africanismos expresa los orígenes bubi del vate. Ya dijo Carlos Bousoño (1993: 21)

\footnotetext{
Y es que el verbo ha nacido y habita entre nosotros con naturalidad: taller, víruta, escoplo, martillo, sierra, clavo.

Barro en manos del alfarero, sencillas las palabras, las de todos los días.
}

10 EmLlo Barón tiene un artículo muy interesante al respeto. Véase Revista de Literatura, tomo LIX, núm. 117, 1997, pp. 67-87. 
La palabra, en manos del vate guineoecuatoriano, tiene poderes insoslayables. En buen antiguo sacerdote, cree en la fuerza de la palabra. Sabe que Dios creó el mundo con las palabras. «Al principio fue el Verbo-dicen las Sagradas Escrituras-y el Verbo se hizo Carne». Y Bokesa crea su mundo poético con palabras. Con San Lucas se valora la palabra como motor de la religión: Jesús perdona los pecados con la palabra; hace los milagros con la palabra; o incluso como en la fábula de Marta y María, prefiere a María, la cual se sienta a escucharle mientras Marta está afanada en preparar la casa. La torre de Babel cae derrumbada por la palabra. Según George Steiner (1998: 13 y ss.) la civilización judeo-cristiana ha puesto una confianza sin par en la palabra y no se ha cuestionado su relación con las cosas ${ }^{11}$.

El lenguaje poético de Ciriaco Bokesa está hecho de proverbios:

Anda hacia adelante, que hacia atrás es siempre de cobardes.

A la lluvia siempre sigue, en coda, la bonanza

(p. 34)

de frases hechas

$$
\begin{aligned}
& \text { (...) Vaya Vd. Con Dios } \\
& \text { (p. } 90)
\end{aligned}
$$

Con amor te lo digo:

¡Hasta luego!

(idem)

Tres a cien

(p. 75)

No queda remedio

(p. 74)

11 Para más información sobre el poder de la palabra, véase RAMón Pérez Parejo, «La desconfianza en la inspiración y en el lenguaje poético», en Revista de Literatura, tomo LX, núm. 119 , enero-junio, pp. 5-30. El vate chileno Huidobro tituló una obra suya Sátiro o el poder de las palabras, Santiago de Chile, Zig-Zag, 1950. 
Muy a menudo el vate juega con el lector por medio del lenguaje coloquial:

$$
\begin{aligned}
& \text { A comprar cerillas, ieh! } \\
& {[. . . . . . . . . . . . . . . . . . . .]} \\
& \text { «! Si no te va, } \\
& \text { te vasm! (...) }
\end{aligned}
$$

o jugando simplemente con las palabras

Te adoro Teodora

$$
\begin{aligned}
& \text { La vida } \\
& \text { es breve } \\
& \text { a los ojos } \\
& \text { de la vida }
\end{aligned}
$$

Segura ausencia, y más segura presencia ausente

(p. 43)

La rueda rueda su rumba Rumbo al recóndito cajón.

(p. 75)

y con la gramática:

y del un al otro extremo ${ }^{12}$ (p. 32)

Eso, que podría interpretarse como llaneza de estilo o poesía prosaica, no es sino un mero capricho del vate, simple juego literario. Cabría recordar que el estilo de Bokesa es muy culto, herencia de su estancia en Salamanca. Tenemos, como muestra, bajel, fugal (p. 57); urdimbre (p. 30); ampo (p. 31); abisal (p. 45); pusilánimes (p. 47); herrumbe, mentecato (p. 88); birla, tañer (p. 20).

El vate va en busca de las palabras. Cuando las encuentra, se percata de que ese camino ha sido infructuoso porque las palabras, a veces, se muestran 
insuficientes para expresar lo que él ha querido comunicar. Desde luego, empieza a buscar apoyo en los adjetivos.

Abundan adjetivos en el poemario que analizamos. Se trata de epítetos especificadores y tipificadores antepuestos o pospuestos.

El adjetivo es uno de los elementos claves de la lírica. Expresa ternura, colorido, sonido, belleza y nos lleva a un mundo de ensueños. Según Luzán (1977: 133),

«Los epítetos sirven, menos para el adorno, que para la brevedad de la locución; porque lo que necesitaría de una larga oración se suple y se dice igualmente con un solo adjetivon.

Entra el adjetivo en los retratos y en la topografía. La repetición de ciertos adjetivos aumenta la belleza del paisaje, el sensualismo y la dulzura poética. Así tenemos en tan solo «Palmeras en hileras» (pp. 38-39) fecundos, altos, juguetona, rojo, maduro, macizo, lechosa, impía, segado, echados, hundidos.

Muchos adjetivos que encontramos en Voces de espumas son epítetos clichés y obedecen a la tradición literaria. Es una herencia de la Generación del 27.

Algunos son epítetos metafóricos, sugestivos e hiperbólicos porque se distinguen bastante del simple epíteto descriptivo. Como si tuviera a la vista ese texto de Pierre Fontanier (1977: 325),

«Un discours sans épithètes ne peut être qu'extrmeêment maigre, ne peut qu'être sans couleur et sans vie».

Ciriaco Bokesa llena sus poemas de epítetos bien seleccionados.

Otro recurso estilístico muy recurrente en nuestro poemario es el adverbio.

Cuando evoca los momentos de sufrimiento del pueblo guineano. Es una vuelta atrás, una analepsis en los tiempos de silencio. Se opone a ahora, momento de paz que simboliza la paloma («Paloma blanca», p. 30). A veces cuando expresa alegría, sensualidad, momentos de goce erótico ( $«$ Mi mujer, p. 69; «Teodora», p. 68)

Cuando abrazas con tus flores

el altar de mi pecho.

(«Teodora», p. 68)

Cuando simboliza el apego a las tradiciones bubi

Mi Virgen,

cuando ante el altar

de tu selva en pico verde - langosta 
llego hasta tus plantas de Madre, sólo sé decirte: «DAME»

$$
\text { ( } \text { Bisila Virgen», p. 46) }
$$

y también la gratitud:

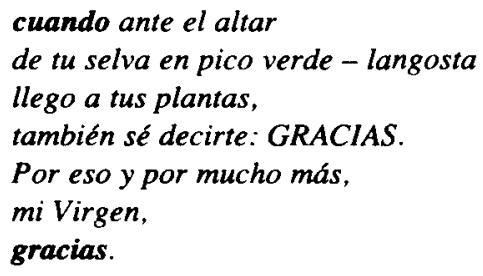

(idem)

Donde sirve para ubicar acontecimientos en lugares precisos. Expresa también el destino del hombre («Auto-nombre», p. 63).

Lo mismo ocurre con aquí, alla con los que el vate nos va indicando su situación en la selva tropical guineoecuatoriana donde pasea de noche, con todo lo que ello conlleva como dificultades.

Según esté empleada en tal o cual poema, la exclamación traduce sentimientos diferentes: angustia existencial («Soliloquio», «Camino del mar»); es un llamamiento al Señor para que tenga piedad del hombre («Soliloquio»). En «Camino del mar», el mundo donde evoluciona el hombre le es ajeno. No sabe a dónde va. La vida está asimilada a un camino hacia el mar, caminante solitario. De ahí l'étonnement, la angustia y las inquietudes del personaje poemático.

La exclamación aparece como un suspiro de alivio después de una larga lucha.

Expresa la alegría en «Lluvia sabrosa» donde el personaje poemático añora su niñez en una tarde de lluvia. Soñando, paraliza y retrocede el tiempo para volver a vivir la alegría de la infancia:

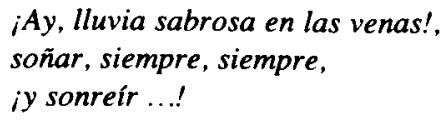

La exclamación se hace, como el poema, ese filtro que media entre el contemplador y lo contemplado y que, de ese modo, condiciona la veracidad de lo percebido.

En «La vida», la exclamación, reforzada por el encabalgamiento versal, es desbordante de alegría: 


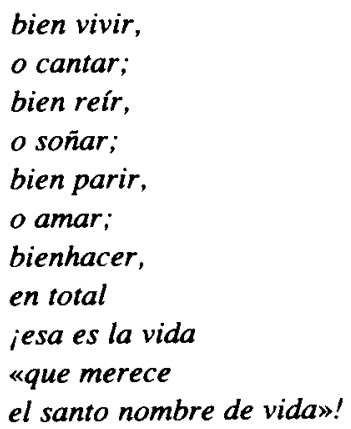

En «Malamba» la exclamación ilustra por una parte la alegría de los borrachos. Por otra, traduce la estupefacción frente a la ignorancia de los mismos discípulos de Baco que no llegan a percibir los daños que causa el alcohol.

El vate guineoecuatoriano no sólo se exclama, sino que también se interroga sobre el arte, su existir, Dios, el destino, el medio ambiente.

La existencia humana es corta. El hombre avanza inexorablemente hacia un destino incierto. Tembloroso, la voz llena de emoción, el vate se pregunta:

¿Será la sonrisa de algún hada que ha pronunciado el lenguaje de la rosa o la calandria?

(«Un sueño con flores», p. 38)

Con la interrogación se interpreta el lenguaje del viento que sopla («Un sueño con flores») y se establece así una comunión entre el hombre y la naturaleza, lo que permite hacer una interpretación plural del lenguaje del viento.

La interrogación interpela al hombre a que se mantenga en contacto permanente con la naturaleza ya que encierra cosas muy importantes como las raíces que alimentan alturas («Palmeras en hileras», p. 39).

En «Oración» el orador inquieto llama al Señor para que le salve. Ahora la interrogación significa interpelación al Ser Supremo, creencia, fe cristiana:

¿Dónde anidar

perdido, sino en Ti,

Oculto Hallazgo,

Intacto Viento,

Fluidez Huidiza, mi Dios, mi Vivo Silencio? 
La metáfora es el adorno poético de mayor categoría estética. Con ella la palabra cobra su máxima carga expresiva. En buen epígono del 27, Ciríaco Bokesa hace un uso abundante de la metáfora en Voces de espumas. Veamos un ejemplo:

El cielo se acuesta

como inmenso paraguas

sobre la alfombra

verde lejana

de la tierra.

(«Arco iris», p. 37)

Y otro donde la metáfora expresa la sabiduría:

Bailan las ideas en el techo canoso

de algún sabio.

(«Verde es la selva», p. 40)

Algunas metáforas recuerdan al mismísimo don Luis de Góngora y Argote por ser muy complicadas.

Mi mujer vendrá.

$Y$, en el río de su voz,

sonarán los peces

su nadar hasta mí.

(«Mi mujer», p. 69)

Más adelante el vate habla de los francos de quien sólo los vel en la ruda esquina del mes («Tres a cien», p. 75), de la oscura carne de la noche ( $\mathrm{A}$ un indeterminado», p. 85), etc.

A veces nos encontramos con imágenes atrevidas a lo Vicente Huidobro:

No llueve fuegos el cielo

[........................]

Va el sol tejiendo

iris de esperanza.

(«Llover», p. 34)

Hombres hay que llueven

desabridos su furia

en palabras, gestos o lagrimas.

(idem) 
El vate emplea metáforas incluso en los monólogos:

\author{
Nubes vagas \\ rondan el firmamento \\ profundo de mi vida, \\ hecha soplo huidizo \\ que, errabundo y en riesgos, \\ va jalonando cuitas \\ por sendas y senderos \\ [.................................] \\ iré siempre jalonando cuitas \\ por sendas y senderos. \\ («Soliloquio», p. 32)
}

En cuanto a la simbología poética muy abundante en el poemario, diré simplemente que el árbol es perennidad, eternidad, ascensión, verticalidad, unión del eje horizontal con el vertical. El mismo papel juega la palmera que además es vino y alimento.

La rosa no recibe ningún tratamiento especial sino que sigue los clichés literarios clásicos: es amor, delicadeza, sensualismo, transcurso del tiempo, lo efímero ( $\ll$ La rosa», p. 36).

La lluvia simboliza tristeza, pesimismo, desesperación, pero es también alegría, ensueño, la niñez añorada. El agua que cae en el tejado parece una canción de cuna. Por eso el vate la alaba («Lluvia sabrosa», p. 43).

El cromatismo añade un matiz de sensualismo a los versos de Voces de espumas. El arco iris halaga la retina con sus variados colores (p. 36). Todo en el paisaje es cromatismo. Las sensaciones más sobresalientes son el verde, el azul, el blanco, el rojo y el rosa. Todo no es sólo belleza y color, sino también olor, dulces fragancias aunque de vez en cuando los versos huelen a Malamba ${ }^{13}$, a Mongorokom ${ }^{14}$ (p. 76), a sawa-sawa ${ }^{15}$ (p. 69), a macaco (p. 63), a topé (p. 19), a pepe-sup ${ }^{16}$ (p. 74) o a gazpacho (p. 23).

De vez en cuando, a través de la prosopopeya, el poeta convierte las cosas inanimadas en actantes: las ideas bailan, la noche avanza, las hojas hablan y se burlan del viento («Perspectiva», p. 42).

13 Zumo de caña de azúcar fermentado.

14 Malamba destilado a más de cien grados C.

is Fruta tropical, de dulcísimo zumo.

16 Salsa a la africana, ligera y muy picante. 
Otro rasgo recurrente del estilo de Bokesa es la antítesis. Traduce inquietud, insatisfacción amorosa ( $\ll$ Nostalgia de ti», p. 43). En «Celia» la oposición ayer/ hoy; niña/ mujer, expresa el paso del tiempo.

Tenemos en «Tres a cien» (p. 75) la repetición diseminada de tres a cien, verso que constituye oraciones nominales, estribillo machacón, como las preguntas infantiles deseosas de alcanzar la verdad y el conocimiento, sabia maestría del encadenamiento de los versos que llevan desgraciadamente al bolsillo pobre del fumador guineoecuatoriano quien, incapaz de ofrecerse un paquete entero de Benson o de Marlboro, se contenta con comprar tres cigarillos a cien francos CFA ${ }^{17}$.

Muchos poemas de Voces de espumas, como «Tres a cien» que estoy analizando, se estructuran narrativamente. Se trata de una estructuración lineal y clara de lo que se cuenta en los versos. los poemas revelan una historia narrada con un principio, unos hechos y un final. Ya señaló Francisco Rico (1991) que la novela y la poesía acrecentarán, a partir de la postmodernidad, sus mutuas concesiones.

La comprensión del mundo para el vate guineoecuatoriano pasa a través del lenguaje, que en su percepción de la realidad es, antes que otra cosa, un fenómeno de lenguaje. El lenguaje introduce en el texto poético, mediante un vehículo narrativo perfectamente integrado en su urdimbre ficticia, las reflexiones sobre el arte, la sociedad, el mundo, Dios, sobre el papel social del mismo poeta, sobre sus inquietudes y su reflejo mediante la escritura poética. Por medio del lenguaje se observa ese derroche de imágenes y sensaciones a través del caleidoscopio bokesano.

El último rasgo de estilo digno de mencionar son los puntos suspensivos que encontramos en 15 de los 69 poemas del libro ${ }^{18}$. Se puede pensar erróneamente que decir nada significa no hay nada que decir. La retórica del silencio no es la imposibilidad de decir, sino la necesaria mudez. El vate cansado de decir calla. La singularidad de la semántica de la ausencia o el silencio es la elocuencia callada. Cuando los puntos suspensivos surgen en cualquier poema de Voces de espumas, suponen momentos de silencio por parte de la voz poética, tal vez momentos en los que la emoción es tanta que ni siquiera puede ser verbializada como en el siguiente caso:

$$
\begin{aligned}
& \text { «Dii estis: sois dioses». } \\
& ¿ \ldots ?
\end{aligned}
$$

17 Para más información sobre la forma litánica o la repetición del estribillo tras cada verso, véase JosE FARDEJAS LEBRERo, «La forma litánica en la poesía del siglo XX», en Revista de Literatura, LVIII, núm. 116, 1996, pp. 399-425.

${ }_{18}$ Pp. 23, 29, 32, 33, 35, 37, 42, 48, 54, 57, 65, 67, 73, 79, 87. Cuento los diez epigramas como un solo poema. 


$$
\begin{array}{r}
¡ O, \text { tal vez, antípodas de Dios! } \\
\text { («Morir», p. 58) }
\end{array}
$$

Entonces diremos con Bousoño (1996) que el poeta no quiere decir nada, tan sólo quiere expresar una emoción. George Steiner (1994: 80), que recuerda la afirmación de Aristóteles: el hombre es animal dotado de palabra, sitúa el silencio en la poesía latina medieval, en Mallarmé y en los simbolistas rusos, y añade: para el escritor que intuye que está en tela de juicio la condición del lenguaje, que la palabra está perdiendo algo de su genio humano, hay abiertos dos caminos, básicamente: tratar de que su propio idioma exprese la crisis general de transmitir por medio de él lo precario y lo vulnerable del acto comunicativo o elegir la retórica suicida del silencio.

¿A qué conclusiones se llega después de leer las Voces de espumas?

1. Ciriaco Bokesa Napo escribió su libro, como el mismo lo anuncia en su POÉTICA, para enganchar en él todo el esplendor y la felicidad del arte. Su obra tiene la extensión y la sinuosidad fluvial del río caudaloso, rapidez del arroyo y la espuma del mar, certería de águila y claridad cristalina. Es un esbelto chorro verbal que va esculpiéndose a sí mismo, que va tatuando en el pecho inmaculado de la página la molécula imperceptible del espíritu.

2. De todas formas, bien puede afirmarse la salud literaria de los textos del poemario cuando comprobamos cómo su maquinaria se pone en marcha.

La sucesión de imágenes visionarias, visiones, símbolos, desplazamientos calificativos, sinestesias, antítesis, africanismos, latinismos, exclamaciones, interrogaciones retóricas, asociaciones emotivas y oníricas, clímax, puntos suspensivos, caracteriza el lenguaje poético de Voces de espumas.

3. La escritura poética conduce a menudo a poemas abiertos basados en la sugerencia de la emoción, al goce estético.

4. Para Bokesa, la poesía consiste en un ejercicio exclusivamente lingüístico, en una búsqueda rigurosa en el eje paradigmático del lenguaje (utilizando la terminología de Jakobson) de tal manera que, como diría Mallarmé (1957: 655-656), el hecho poético por excelencia no es más que el lenguaje.

5. No es que Bokesa quisiera situar el lenguaje, como hacían los modernistas, en un punto de máxima distancia respecto a la lengua hablada, sino que llena la escritura poética de localismos y latinismos. En conjunto, esas palabras raras de muy diversas procedencias configuran una lengua literaria creada por el vate, y que resulta extraña tanto para el español como para el guineoecuatoriano. Más que por su significación literaria, que en muchos ejemplos el lector desconoce, esas palabras son expresivas en lo que connotan. Los localismos, por ejemplo, sugieren analfabetismo, marginalidad, violencia, in- 
cluso delincuencia intelectual. En cambio los latinismos, en lugar de sugerir la aristocracia intelectual o la nobleza, sugieren pedantismo, aislamiento, inadaptación social.

6. La poesía se convierte en un juego de perspectivas en el que los personajes poemáticos se confunden, se distancian, o dialogan.

7. Lo que hoy tenemos de Bokesa no son poesías, sino toda una poética; no unos poemas, sino un método poético, una nueva tradición, un camino que deben seguir los poetas guineoecuatorianos, o todos los poetas africanos hispanoparlantes. Las poesía guineoecuatoriana desde Bokesa entra en una nueva tradición, la «Bokesana», como con Rimas la poesía española entró en una nueva tradición, la becqueriana, que sustituyo a la garcilacista.

8. El vate guineano se adelantó mucho respecto a sus compatriotas ${ }^{19}$, a sus coetáneos, a los escritores francófonos quienes, escribiendo en las mismas condiciones históricas en las que escribió Bokesa, virtieron más hacia el insulto.

9. Los hombres - más aún los poetas--, cuando viven, no tienen la importancia que la historia les presta.

10. Con don Ciriaco Bokesa Napo la poesía guineoecuatoriana puede instalarse en su primera Edad de Oro. No se trata de un manojo de poemas más o menos sentidos. Se trata, reiterémoslo, de un nuevo modo de entender el quehacer poético.

BiBliografia

BOKESA NAPO, Ciriaco (1989): «Ekomo, toda una novela», África 2000, núms. 10-11. pp. 95-97.

- (1987): Voces de espumas, Malabo, CCHG.

Bolekia BolekÁ, Justo (1999), Löbëla, Madrid, SIAL.

Bousoño, CARlos (1993): El ojo de la aguja, Barcelona, Tuquest, Nuevos textos sagrados.

- (1996): Conferencia de clausura leída en la Universidad Internacional Menéndez Pelayo de Valencia el 19 de septiembre de 1996: « Sentido y situación de la poesía de los años 50: Francisco Brines y Claudio Rodríguez. La escritura poética de los 50: historia y sistema de un grupo generacional».

FARDEJAS Lebrero, José (1996): «La forma litánica en la poesía del siglo XX», $R e$ vista de Literatura, LVIII, núm. 116, pp. 399-425.

FONTANIER, Pierre (1977): Les figures du style, Paris, Flamarion.

19 Tengo ante la vista el primer poemario de Justo Bolekia BoleKA, Löbëla, también de nacionalidad guineoecuatoriana, que me propongo analizar en un próximo trabajo. 
HuIDOBRo, Vicente (1950): Sátiro o el poder de las palabras, Santiago de Chile, ZigZag,.

LÓPEZ HidAlgo, José Antonio (1993): «La novela en Guinea Ecuatorial», África 2000 , núm. 20, pp. 42-44.

LuZÁN, Ignacio de (1977): La poética o reglas de la poesía en general y sus principales especies, Barcelona, Labor.

Mallarmé, Stéphane (1957): Oeuvres, Paris, Gallimard, t. I.

MARTIN DEL Molino, Amador (1989): Los bubi. Ritos y creencias, Malabo, CCHG.

MENDOGO, Dieudonné (1997): «Mujer y creación literaria en Guinea Ecuatorial», Epos, núm. XIII, pp. 209-218.

NGOM FAYE, Mbare (1996): Diálogos con Guinea: panorama de la literatura guineoecuatoriana de expresión castellana a través de sus protagonistas, Madrid, Labrys 54.

- (1993): «La literatura de expresión castellana: la creación literaria en Guinea Ecuatorial», HISPANIA, núm. 76, pp. 410-418.

OTERO, Blas de (1992): Ancia, Madrid, Visor.

Pérez PAREjo, Ramón: «La desconfianza en la inspiración y en el lenguaje poético», Revista de Literatura, tomo LX, núm. 119, enero-junio, pp. 5-30.

- (1997): Revista de Literatura, tomo LIX, núm. 117, pp. 67-87.

RICO, Francisco (1991): «De hoy para mañana: la literatura de la libertad» en El país (Especial Francfort 91), 9 de octubre de 1991, pp. 2-3.

STEINER, Georges (1994): Lenguaje y silencio. Ensayos sobre la literatura, el lenguaje y lo inhumano, Barcelona, Gedisa.

- (1998): Presencias reales. ¿Hay algo en lo que decimos? Barcelona, Destino. 